\title{
Migration
}

\section{The potential for inclusive forest management}

\author{
Kartika Sari Juniwaty, Moira Moeliono and Cynthia Maharani
}

\section{Key messages}

- For forest communities, migration is an important livelihood strategy. The primary driver of migration in our research areas in Malinau has changed from employment to education. In Kapuas Hulu, migration for high-level education is also gradually increasing, but here, finding better employment is still the most important reason for migration.

- Young, educated migrants from Malinau, interviewed in the city where they are studying, are eager to return to their homeland. They reported that they hope to get a formal job, but would like to maintain agriculture/forestry as an additional activity.

- In Kapuas Hulu, particularly in areas where the main - or only - economic opportunity is swidden, men and young people move to find better employment outside their village. Women are left behind to take care of swidden and other activities in the village.

- $\quad$ Economic migrants are expected to send remittances back, while education migrants receive support from home. These different patterns of migration have implications for forest management and policies.

- Youth, especially those returning from education migration, can become agents of change in local communities; for example, in government programs, such as Forest Management Units and social forestry programs. Educated migrants who have not returned can market the social forestry outputs.

- Women, generally, are an important source of labor and knowledge for social forestry programs and need to be able to obtain benefits from such programs.

- Steps toward the long term sustainability of the social forestry program include: mapping the skills needed; introducing the program to the younger generation; offering special incentives within the existing scholarship schemes to encourage students to become involved in social forestry; and using information technology to develop capacity and monitor the social forestry progress.

\section{Background}

Southeast Asia is a region on the move (Rigg 2013). Millions of Southeast Asian people are crossing the borders of their villages into neighboring regions, cities and even countries, mostly to find work. Improved infrastructure and access to transportation have also increased mobility in terms of both frequency and distance. In 2015, it was estimated that 3.9 million Indonesian people were living outside the country, with Saudi Arabia and Malaysia being the two main destinations for work. Working migrants sent a total of USD 10 billion back to their families. According to the last census in 2010, a further 27.8 million individuals have moved from their birth province, and 4.8 million individuals have moved to a different province in the last 5 years (Thung and Juniwaty 2018).

Migration is not a new phenomenon. It is a livelihood strategy, as well as a strategy for investment and resilience. Remittances from migration have consequences for forests through changes in use and management (Hecht et al. 2015). Migration will likely produce different outcomes for landscapes and forests, depending on the social and environmental contexts to and from which people migrate. More research is needed on the links between migration, forest livelihoods and sustainable forest management. However, national statistical data on migration lack information on forest-related variables.

The Center for International Forestry Research (CIFOR) is working to fill this knowledge gap through studies on the forestmigration nexus in eight geographically diverse countries: Burkina Faso, Ethiopia, Indonesia, Laos, Nepal, Peru, Tajikistan and Vietnam. In Indonesia, two different research project were conducted at different research sites. The results were combined and compared to be presented for this Infobrief.

The first research project was conducted in Kapuas Hulu Regency in West Kalimantan and the second one was in Malinau Regency in North Kalimantan. Both regencies are forest 
conservation regencies. Household surveys were conducted in four villages in Kapuas Hulu and eight villages in Malinau. In each site, the villages surveyed are at different stages of development; villages closer to urban centers tend to have a better infrastructure with more diverse economic opportunities, for example mining and oil palm. Villages located in remote areas have fewer livelihood options, mainly agriculture and forestry, with some formal employment in public sectors.

The communities studied were mostly indigenous 'Dayak' people. Although tribes and sub-tribes are differed between villages, their day-to-day activities were similar. They have all practiced swidden agriculture for many generations. Community members used to migrate in large groups to nearby Malaysia for work, staying for some time. In Kapuas Hulu, this tradition is called bejalai; while in Malinau, it is peselai.

This InfoBrief is based on the findings of field studies in Kapuas Hulu and Malinau and discussions with relevant stakeholders. The aims of the study were to:

- examine the migration-forest nexus, exploring the current patterns and drivers of migration in forest communities and their implication for livelihood strategies;

- $\quad$ link empirical results to current forestry policies, providing recommendations to take advantage of what migration can offer for sustainable forest management.

\section{Why is the migration issue important for policymakers?}

While Indonesia has achieved much progress in development, there are regional disparities and inequalities in economic opportunity. This drives people to move from disadvantaged areas to areas where better opportunities are thought to exist. The government is implementing various projects to reduce the disparities. While the programs were not intended to specifically address migration, they may affect migration and migration may implicitly affect policy formulation and its implementation.

Lack of information about people's mobility and the resulting dynamics of people's relation to forest and land, both in their areas of origin and destination, complicates the implementation of forestry policies. Tenure, for example, is affected by migration as different groups may claim land which was abandoned for a long time and then occupied by new migrants. Even though the first inhabitants had moved decades ago, they might come back to claim the land. This multiple claims of land rights results social tension and complicates the implementation of government policy such as social forestry.

Similarly, communities in rural areas where the men have migrated to find work can lack the labor to participate in government or development programs; at the same time, women and older people can be marginalized. By understanding the population dynamics, challenges in ensuring equal participation in projects can be addressed in the implementation design. Without an understanding of migration, a program may not tap the potential that migration could bring to the program.

\section{What are the recent findings from forest migration research? ${ }^{1}$}

\section{Patterns are changing as development occurs in the}

areas. In the past, communities in Kapuas Hulu and Malinau were highly mobile and frequently migrated to Malaysia, as a traditional rite of passage to adulthood, to seek better economic opportunities, and to buy groceries. Development on the Indonesian side and more restrictive border controls have constrained this movement, and most people are now settled in permanent communities along the border.

In the early 2000s, decentralization triggered political and economic change in remote areas, such as the border with Malaysia in northern Kalimantan. New districts were established, bringing new opportunities, such as government jobs, casual employment and increased private investment. These developments reduced the need to out-migrate to find employment and, at the same time, increased in-migration to the areas. Intercensal Population Surveys (SUPAS) 2015 data shows that Malinau had positive net-migration: $7.87 \%$ of the population moved in, and 3.94\% moved out in the five years before the survey (recent migration). This rate was even higher than that for in-migration to DKI Jakarta, the capital, which was only 4.9\% for the same period (BPS 2016a). The survey revealed the opposite trend for Kapuas Hulu. It had a negative net-migration rate with 1.6\% recent in-migration and $2.19 \%$ out-migration (BPS 2016b). More people in Kapuas Hulu are out-migrating for works or further their education, while lower in-migration is often linked to migrant workers coming to work in newly established oil palm plantations. However, in terms of lifetime migrants, both districts have positive net migration: 24.64\% and $8.02 \%$ of the Malinau and Kapuas Hulu population were born outside the region, respectively.

In our research sites, circular migration to Malaysia for casual employment purposes is still part of the livelihood strategy for several villages with limited development.

\section{Externally driven development, such as oil palm development, mining investment and government infrastructure construction projects, in and around forested areas might not be enough to improve livelihoods in}

\footnotetext{
1 The materials presented in this section are based on the findings of the CIFOR Migration and Forest Research Program in Malinau (Juniwaty et al. forthcoming) and Kapuas Hulu (Maharani et al. 2019) unless
} otherwise stated. 
the long term. Although private investment in resource exploitation provides cash income in the short term, it tends to have negative impacts in the long term. When resources are depleted, companies typically move on, leaving local people with the environmental consequences. Governmentfunded projects are not always available and are also typically short term, hence the cash for work program is limited. More sustainable income sources are needed in the villages. Nevertheless, short-term economic improvement coupled with better understanding of the value of education to improve employment prospects, has encouraged households to send their children away to school.

Youth migration for education is a rising trend, as a longterm strategy to improve livelihoods. Households are willing to work harder to fund education in exchange for expected future returns. Investment in education reverses the flow of money from the origin areas to the destination areas. Responses to migration for education differ across households, depending on current livelihoods and available labor in the households. Households who rely on more formal income, such as civil servant/village employment, those who work for oil palm/ mining companies, or those relying on remittances are more secure and may not need to adjust their livelihood. However, households that rely on agriculture and the forest need to intensify their efforts to raise enough cash for education. Women in Setulang, for example, plant more vegetables to be sold in the market, while men in Apo Kayan, hunt or gathering construction timber and gaharu. ${ }^{2}$ Some households manage larger areas of swidden land to increase production. The financial burden of migration clearly poses a challenge for these households. Livelihood options with a regular and more frequent income stream are needed in these communities.

Future aspirations of youth migrants from the forest frontier were explored by interviewing eight students at the destination city: Samarinda. All expressed the wish to eventually return to the village. They believed returning means that they can contribute to village development. This is contrary to the common belief that most youth educated outside their home village tend to stay in the destination areas to find better employment. However, our study in villages shows that while youth migrants were eager to return, the capacity of the villages in absorbing the returnees was limited. In the research villages at both locations, we found young educated returnee migrants that had returned home. Some have returned for family reasons or financial reasons, because they cannot afford the living costs while searching for a job. Some are obliged to return due to receiving a local government scholarship. Some simply prefer to live in the village. The returnees were working in public services, such as teaching, forest management or working in the

2 Gaharu is fungus-infected wood which produces a fragrance. This is valuable as an ingredient in medicines and perfumes (Eghenter 2006). village office. If there were mining or oil palm plantations nearby, returnees were most likely to seek employment there. Those who could not get a job, returned to the family fields or became gaharu seekers.

Different youth perspectives on participation in agriculture emerged from the two research areas. The youth in Malinau mentioned that they are still interested in working in agriculture/ agroforestry. During group discussions and in-depth interviews, we found that while they were reluctant to work in the agriculture/forestry sector, they were still willing to combine such work with employment that generated more secure and regular income. This commitment to agriculture reflects the cultural belief that without farming there will be no food. It conforms to community practice and also can generate a good income. In Kapuas Hulu, however, the returning young migrants tend to work at oil palm plantations and have no interest in continuing swidden, which they consider hard work with little monetary return.

Both migration for employment and education create challenges for the women left behind. In two villages without oil palm plantations in Kapuas Hulu, migration for employment is quite high. The migrants were mostly men who left their families behind, putting the burden of swidden on the women. Furthermore, financing education may increase the burden for women. Consequently, some women spend more time managing their land to produce rice or vegetables, selling vegetables door to door or at the market, and doing casual work both in the village or in Malaysia. For domestic work in Malaysia, women traveled in small groups and stayed 2-3 weeks, meaning that they left their land and also other domestic obligations.

\section{Considering migration patterns for forest management policies: Risks and opportunities}

Our research in Malinau highlights the urgency of investing in job creation and economic opportunities for young migrant returnees in forest frontiers. Higher education attainment alone will not translate into expanded economic opportunities for the next generation. The current labor market is unlikely to absorb the rise educated youth. Broader efforts are needed to promote jobs for the next generation in the forest frontier. The Forest Management Unit (FMU) and social forestry program can contribute to these efforts by engaging more young people, which will also expand economic opportunities for them. On the other hand, successful implementation of FMU and social forestry programs will also require capable and committed managers. The migrants returnee can play important role by applying the skills that they have learned to create and enforce rules to govern and identify opportunities to expand/ strengthen their livelihoods. 
The forestry sector could contribute significantly to economic development. However, past forest governance has failed to manage forest sustainably and provide benefits for local people. In an effort to improve forest governance, the government has adopted the FMU system, whereby local managers manage the forest. Medium-term development plans for 2015-2019 aim to distribute all the forest land to 629 FMUs by 2019 (Bappenas 2015). The government has also initiated a program to benefit local communities by designating 12.7 million hectares of forest for social forestry schemes. These programs aim to improve well-being and preserve the environment. However, transfering forest management to the local level is not easy: there is a shortage of capacity and human capital. Although migration for education has become the norm in Indonesia, the lack of livelihood options in the area of origin has discouraged the educated youth from returning. If they do return, they cannot fulfill their potential. Improved livelihood options will encourage educated people to return and thereby drive economic development.

\section{FMU is "a public service provider, a permanent} management entity and an operational unit of a manageable and controllable size of forest under the responsibility of national and subnational governments" (FORCLIME 2015). The goal of FMUs is to reduce deforestation and forest degradation by improving forest governance. The size of the FMU varies based on the landscape. The smallest is 4,500 ha and the largest 800,000 ha, with an average size of 133,000 ha (FORCLIME 2015). Early evaluations of FMU implementation show that progress is not as high as expected. This is due to changes in policies that have made legal roles and responsibilities unclear, a lack of human resources and technical expertise among members, and a lack of cohesion in working with other local stakeholders (Thung, 2019).

\section{Social forestry is "potentially a new mode of forest} management empowering local managers and hence, allowing integration of diverse local practices and support of local livelihoods" (Moeliono et al. 2017). The government is currently focusing on the social forestry program. The target has been expanded to allocate 12.7 million hectares of land to local communities under five different schemes: village forests, community forests, community plantation forests, customary forest and partnership forest. These different schemes provide legal access and different options for use of the forest for local benefit. The aim is to reduce poverty, unemployment and inequalities in forest management. In addition to formal access to forestland, the government social forestry program provides forest communities with additional support, such as financial capital, technical skills, capacity development and market access. Agroforestry, non-timber forest product collection and eco-tourism can be conducted under social forestry. The most recent figure shows that 2.5 million hectares of land have been distributed to 602,000 households in 5,450 groups. This is an average of 4 hectares per household and 110 households per group. ${ }^{3}$

Although a national program, social forestry will be best managed at local level through the FMUs. Herawati et al. (2017) and Zakaria et al. (2018) suggest that FMUs should play a greater role in social forestry. They propose giving FMUs responsibility for helping communities to obtain legal rights for forest management/customary ownership, as well as supporting communities once they have received the permits. Assigning FMUs to review and approve social forestry applications will streamline the process and thereby help to achieve the social forestry target. However, the capacity of FMUs must be improved, especially since they are expected to provide technical and institutional support, as well as business management skills. They are also expected to do business in partnership with local communities or third parties.

\section{Coordination and collaborative effort to strengthen the} social forestry program is key to its success. The program acts synergistically with the Village Fund program, in which social forestry is a priority funding activity. The social forestry program can also access finance through People's Kredit (Kredit Usaha Rakyat, KUR), a government-subsidized program, and tapping financing schemes facilitated through anda revolving fund facility related to land and forest restoration. ${ }^{4}$ In addition, civil society can support communities in developing their social forestry proposals for licensing and business development. Further collaboration aiming to increase the capacity of the groups and facilitators should be the next direction.

\section{While social forestry has potential benefits, it also has} many challenges. One challenge widely discussed is the lack of capacity of local communities/farmer groups. Groups need support in preparing their license application, as well as in sustainably managing the business after receiving a permit. Setulang Village, Malinau, supported by FORCLIME, obtained a Village Forest (Hutan Desa) permit in 2013. The villagers used the forest to establish a tourism village. The local forest management effort in the form of the preserved Tana Olen $^{5}$ - has attracted many visitors, both local and international (Ernawati 2017). However, during our visits and also in the sub-national workshop, the manager of the tourism village mentioned that they lack skilled personnel to expand the business. Expertise is needed to prepare an inclusive business model expansion plan and to manage the day-to-day activities

3 Bambang Supriyanto, Directorate General for Social Forestry and Environmental Partnership, Ministry of Environment and Policy presentation on February 26, 2019

4 Ministry of Finance and Ministry of Environment and Forestry Joint Regulation No. 04/PMK.02/2012 and PB.1/Menhut II/2011

5 Tana Olen literally means the forbidden forest; the villagers are forbidden to clear, farm or extract forest products from the land without prior approval from the customary leaders. 
the tourism village. Another example, comes from Kalibiru eco-tourism in Yogyakarta, which also has a well-established a tourism village. ${ }^{6}$ However, such success gives rise to competition. Additional business ideas are needed to maintain a competitive advantage and their revenue stream. Villages in Apo Kayan have submitted their customary forest (Hutan Adat) application. Learning from the predecessor's experience, they need capacity to develop institutional and business plans, and how to manage the business.

Experience from Setulang and Kalibiru shows a lack of entrepreneurial skills and ability to establish a sustainable business. To help local people establish and maintain social forestry as an enterprise, the Ministry of Environment and Forestry has recruited and trained facilitators. However, there is still a shortage of 1,400 facilitators. Facilitator training is limited to 20 hours for seven modules, an average of 3 hours per module (Sukarelawanto, 2018). Furthermore, facilitators are usually from outside the group and typically stay for only a year. Clearly, there is a need to improve the capacity of the groups themselves.

\section{The changing pattern of migration of young people} from forest areas and their perspectives on the future of agriculture (and forestry) provides opportunities and challenges. More efforts are needed to incentivize youth to be agents of change, supporting forest management programs such as FMUs and social forestry. The potential benefit of including women should not be neglected. Research has shown that women have different knowledge to men. They also tend to utilize forest differently (Sunderland et al. 2014). The involvement of men and women in the social forestry group could provide some advantages in the division of labor within the group, with women and men taking on different roles and responsibilities. Studies in diverse settings have shown that women are better at collaborating, which can be useful for group dynamics and can improve group outcomes (Fenwick and Neal 2002; Berge et al. 2016). Social forestry could open up opportunities for women to manage land collaboratively and engage in the entrepreneurship activities that will benefit both them and the environment. However, as other studies have shown, extra effort is needed to inform women about these options and provide necessary support (Maharani et al. 2019).

\section{Young people can potentially fill the capacity gap in forest} management. First, they are more likely to be technology literate than the previous generation. Second, it is in their interests to improve management of forests for the future. The younger generation might have fresh new ideas and energy.

6 As mentioned by Mr. Sadali from HKM Kalibiru at the Brownbag Discussion "Social Forestry and Forestland tenure in Indonesia" at CIFOR campus, February 26, 2019.
They may bring a different perspective to problem solving that can complement the groups' ideas.

There are many good examples of youth involvement in forest management. In Setulang, for example, the manager is a young, educated migrant, who chose to return to develop the tourism village. A few young returnees found work in the tourism village and others are currently studying tourism in Jawa and are expected to return. In Kalibiru, the tourism village also has attracted young, educated migrants to return and work in the village. FMUs have hosted undergraduate student interns from forestry departments all over the country to learn and also provide a useful resource for FMU in doing their tasks.

\section{While there is potential, there are also challenges} associated with youth involvement in forest management. Potential challenges include maintaining the cohesion of the group and whether or not the older generation accepts the input of the younger generation. Specifically, educated returning migrants have been exposed to life outside their homeland. They might have different views on the way things should be done. While knowledge and cultural exposure from outside can be beneficial, it might also create some tension. Therefore, the decision to involve the younger generation in social forestry groups should be discussed and approved by other members of the group.

\section{Despite huge efforts in advocacy and socialization of} gender mainstreaming, such those extensively conducted by FORCLIME, Desmiwati (2016) found that gender mainstreaming has not been well implemented in social forestry. There is still no aggregate information on how many women or percentage of women are involved in social forestry, which is the simplest indicator of gender involvement. The online database of social forestry showed the membership unit as the household, with no further breakdown of household members participating in the social forestry? It is assumed that within households there will be a husband and wife. Both usually work in social forestry, but the wife's contribution is never recorded (Desmiwati 2016). However, the current Minister of Environment and Forestry has shown on many occasions that she has a strong commitment to gender mainstreaming and plans for affirmative action. ${ }^{8}$

\section{Calls to action}

Many institutions, including FORCLIME, have implemented capacity-building programs for local communities. However, there is a need for a more extensive and systematic effort

7 The online database can be accessed through https://new-dotsinav-perhutanan-sosial.appspot.com/usulan

8 Press realese Ministry of Environment and Forestry, No. SP. 166 / HUMAS/PP/HMS.3/03/2018 March, 20, 2018. 
to support youths and women to engage in social forestry programs in their communities. Information and technology is essential to attract young people, to develop capacity and to better monitor forest management programs. Below, we outline general and then more specific recommendations for the engagement of youth and women.

\section{General recommendations}

Scale up projects that increase the awareness of young people of forest management. These should include more detailed information on the importance of forests, both locally and globally, and disseminate information about FMUs and social forestry. Deeper and longer-term involvement with communities will provide a long-lasting effect. CIFOR's earlier involvement in Setulang, for example, has resulted in the precise mapping of Tana Olen, which in turn has made people more aware and appreciative of their forest (Limberg et al. 2007). There are several good initiatives working to increase awareness on the importance of forest (e.g. Fascinating World of Forestry), to engage larger community to plant trees (e.g. Rawat Bumi) and to encourage young people to participate in conservation effort (e.g. Biodiversity Warriors) Lessons learned and material from these initiatives can be used to develop tailored material for local young people and women. Educational material should be developed with the forest communities, and include best practices in local forest management. Socialization can use formal mechanisms through the school curriculum at various levels or involve volunteer groups, who can collaborate in initiatives.

\section{Engage young local people and women in social forestry} programs and FMU. More young people, especially those returning to the villages, need to be recruited into the social forestry program or FMUs. They can be given roles as facilitators, business managers or local staff in an FMU. In addition, capacity building through on -the -job- training and monetary remuneration as a rewards is important to sustain the performance of these young people. Educated migrants in the destination, on the other hand, can be marketing agent of the social forestry outputs. Local communities can educate the next generation to manage forests under social forestry schemes. Equal access to information about social forestry is vital. In social forestry, for example, the Social Forestry Acceleration Working Group (Kelompok Kerja Percepatan Perhutanan Sosial, Pokja PPS) currently invites social forestry proposals from groups. In the future, more attention should be given to including young people and women in social forestry. The Ministry of Environment and Forestry has introduced the Bakti Rimbawan program that recruits young graduates from senior high school and higher education to the forestry department. Their presence may encourage local youths to participate in forest preservation efforts.

Utilize information technology as a tool to develop capacity and better monitor the forest management programs and, at the same time, attract young people. As the numbers of FMUs and social forestry are scaled up, it might not be effective to rely on face-to-face training sessions. The use of information technology can fill the gap through a wide range of long-distance learning materials and webinars which can reach larger audiences. There are readily available materials from civil society organization, media, etc. These could be collated on a single website. New materials can be produced documenting lessons learned from successful groups/FMU or supplying other important but missing materials. The website can be used to store a directory of social forestry groups and FMU, what kind of activities they are doing, a discussion forum, a market place for social forestry products and membership lists including members' gender and age, and possibly their socio-economic status. This website could be developed as an extension of the current monitoring system of the program (SiNav PS). Collecting information on progress on a regular basis will track the progress of the groups and impact of the program. The website can continually monitor the development of the groups. The use of technology may also attract more young people to the sector.

\section{Specific calls to action to make the younger generation champions of forest management}

Identify what kinds of skills and qualifications are needed for FMU and social forestry development. An evaluation of how the current curriculum of the vocational forestry high schools and higher academic education might support social forestry and FMUs is needed. The gaps should be identified and adressed by revising the curriculum, if possible. Different departments at the university level could work together to develop a curriculum specifically for students who are interested in social forestry; for example, forestry, business and art departments. This specialized curriculum can later be adapted to the senior high school level. Information should be collected from current forestry students on whether they are willing to work for FMU. Barriers preventing them from doing this should be identified and incentives developed. Opportunities should be provided to do student study service (Kuliah Kerja Nyata, KKN) in forest management. Currently, forestry students can do KKN in FMU and National Parks. This program could be expanded to cover the needs of the social forestry program. Students from different majors, such as business, arts, agriculture, food technology, sociology and environmental studies, could also be involved. The training material for the facilitators of the social forestry program can also be updated following the results of the skills and qualifications assessment.

\section{Improve the opportunities for young people from} forest areas to access higher education in a wide range of subjects related to social forestry. The current local government-sponsored scholarship program mainly focuses on public services, such as teaching or nursing; students 
should be allowed to choose wider subjects, such as business management, natural resources management, languages, art and computer science. Scholarships at the national level, such as the affirmative higher education (Afirmasi Pendidikan Tinggi-ADIK) and BidikMisi scholarships should provide greater incentives for potential beneficiaries who are eager to return to their village to support development; for example, by providing these potential agents of change with specific quotas, monitoring tools and imposing penalties to make sure that they return to their home area after finishing their study.

\section{Specific calls to action to improve women's involvement in forest management ${ }^{9}$}

\section{Improve the opportunities for women to participate} in social forestry, but still consider their preferences. It is understood that women have domestic, productive and also social-cultural roles (Herawati et al. 2019). Hence, their participation in social forestry must consider their preferences and needs. It is essential to provide information and build capacity for women's participation. A first step to make women more visible is to collect gender-disaggregated data on participation. This information can form the basis for gender analysis in social forestry. If the data analysis shows inequality of access for women to the social forestry program, then it is essential to implement affirmative policies for the involvement of women in social forestry. It is also essential at the group level to ensure fair division of labor and benefit sharing, are fair and that women are not discriminated against in the group. Specifically, in relation to households where the husband is working away, additional attention should be given to ensuring the participation of the women who remain.

\section{References}

Bappenas. 2015. Rencana Pembangunan Jangka Menengah Nasional [National Medium-Term Development Plans] 20152019. Jakarta: Bappenas.

Berge, LIO, Juniwaty KS and Sekei LH. 2016. Gender composition and group dynamics: Evidence from a laboratory experiment with microfinance clients. Journal of Economic Behavior and Organization 131:1-20.

[BPS] Badan Pusat Statistik. 2016a. Statistics of Migration Kalimantan Utara. Results of the 2015 Intercensal Population Survey. Jakarta, Indonesia: Badan Pusat Statistik.

[BPS] Badan Pusat Statistik. 2016b. Statistics of Migration Kalimantan Barat. Results of the 2015 Intercensal Population Survey. Jakarta, Indonesia: Badan Pusat Statistik.

Desmiwati, NFN. 2016. Quo vadis gender mainstreaming in public policy of forestry sector: Case of Social Forestry

9 Initially, left behind women will be the focus of this call to action. However, as there is still lack of information on women's involvement in social forestry, we recommend that women's contribution should be made more visible in social forestry.

\section{Acknowledgments}

This InfoBrief was built on discussions during the CIFORFORCLIME joint workshop on "Development of Forestry Intervention and Changes in Migration: How is the Link?" organized in Tarakan and Jakarta on 13 and 18 December 2018. We are grateful to Forest and Climate Change (FORCLIME) for the encouragement and generous support that made these workshops a success. Participants of the workshops are gratefully acknowledged for their contributions to this brief. Our gratitude goes to all the respondents for their patient answers and warm hospitality during the fieldwork in both locations, and all the field research teams, including the Center for Social Forestry, Universitas Mulawarman. We sincerely thank Shintia Arwida, Georg Buchholz, Jo Kumala Dewi, Tuti Herawati, Nining Liswanti, Yussi Nadia, and Wandojo Siswanto for insightful suggestions.

The study in Malinau was conducted under the research "Understanding Migration and Remittances to Improve Forest Management Project and Policies" in partnership with Forest and Climate Change (FORCLIME) Program. CIFOR migration research and FORCLIME receive financial support from the Federal Ministry for Economic Cooperation and Development, Germany.

The study in Kapuas Hulu was conducted under the ASEAN-Swiss Partnership on Social Forestry and Climate Change (ASFCC) funded by the Swiss Agency for Development and Cooperation (SDC). We thank the ASFCC and the AWG-SF partners (ASEAN Working Group for Social Forestry) for their support during this research.

Program in Indonesia. Jurnal Penelitian Ekosistem Dipterokarpa 2(2): 95-110.

Eghenter C. 2006. Movements, social entitlements and economic fortunes in the forests of the interior of Borneo. In De Jong et al., eds. The Social Ecology of Tropical Forests: Migration, Populations and Frontiers. Kyoto: Kyoto University Press \& Trans Pacific Press. 228-46.

Ernawati, J. 2017. Tane' Olen Setulang. Omens of the Isij Bird for the Oma Lung Tribe. A tradition of forest conservation at Setulang Village, Malinau, North Kalimantan. Malinau, Indonesia: Tourism Village Setulang.

Fenwick GD and Neal DJ. 2002. Effect of gender composition on group performance. Gender, Work, and Organization 8(2):205-225.

[FORCLIME] Forest and Climate Change Programme. 2015. Development of Forest Management Units. Lessons Learned for Scaling Up. Bonn and Eschborn, Germany: Deutsche Gesellschaft für Internationale Zusammenarbeit (GIZ) GmbH. 
Hecht S, Yang AL, Basnett BS, Padoch C and Peluso NL. 2015. People in motion, forests in transition: Trends in migration, urbanization, and remittances and their effects on tropical forests. Occasional Paper 142. Bogor, Indonesia: CIFOR. Herawati, T., Liswanti N, Banjade MR, and Mwangi E. 2017. Forest Tenure reform implementation in Lampung Province: From screnarios to action. CIFOR Info Brief No. 169. Bogor, Indonesia: CIFOR.

Herawati, T, Rohadi D, Rahmat M and Winarno B. 2019. An exploration of the gender equity in household: A result from peatland based community in Riau. Biodiversitas 20(3):853-861.

Juniwaty, KS, Sijapati-Basnett B, Thung PH, Sanjaya IM, Busra MI. Forthcoming. Connecting the dots in the forest - migration nexus: A case study from Malinau, Indonesia. Working Paper. Bogor, Indonesia: CIFOR.

Limberg G, Iwan R, Moeliono M, Sudana M and Wollenberg E. 2007. Community-based forestry and management planning. In: Gunarso P, Setyawati T, Sunderland T and Shackleton C, ed. Managing Forest Resources in a Decentralized Environment: Lessons Learnt from the Malinau Research Forest, East Kalimantan, Indonesia. Bogor, Indonesia: CIFOR. 107-27.

Maharani CD, Moeliono M, Wong GY, Brockhous M., Carmenta R., and Kallio M. 2019. Development and equity: a gendered inquiry in a swidden landscape. Forest Policy and Economics 101:120-128.
Moeliono M, Pham TT, Indah WB, Wong GY and Brockhaus M. 2017. Social forestry: Why and for whom? A comparison of policies in Vietnam and Indonesia. Forest and Society 1(2):78-97.

Rigg, J. 2013. From Rural to Urban: A Geography of Boundary Crossing in Southeast Asia. TRaNS: Trans-Regional and National Studies of Southeast Asia 1:5-26.

Sunderland T, Ramadhani A, Angelsen A, Babigumira A, Ickowitz A, Paumgarten F, Reyes-Garcia V and Shively, G. 2014. Challenging perceptions about men, women and forest product use: A global comparative study. World Development 64: S56-S66.

Sukarelawanto E. 2018. Pengelolaan Perhutanan Sosial Kekurangan 1.400 Pendamping. Bisnis.com. https://ekonomi. bisnis.com/read/20181113/99/859389/pengelolaanperhutanan-sosial-kekurangan-1400-pendamping

Thung PH and Juniwaty KS. 2018. Missing links in the forestmigration nexus: An analysis of trends, literature and data sources. Occasional Paper 186. Bogor, Indonesia: CIFOR.

Thung, PH. 2019. Decentralization of government and forestry in Indonesia. Working Paper 249. Bogor, Indonesia: CIFOR.

Zakaria RY, Wiyono EB, Firdaus AY, Suharjito D, Muhsi MA, Suwito, Salam R, Aprianto TC and Uliyah L. (2018). Perhutanan Sosial: Dari Slogan menjadi Program- Naskah Akademik Reformulasi Kebijakan Perhutanan Sosial. Jakarta: Sekretariat Reforma Agraria dan Perhutanan Sosial.

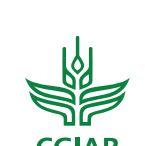

RESEARCH

Forests, Trees and

Agroforestry

The CGIAR Research Program on Forests, Trees and Agroforestry (FTA) is the world's largest research for development program to enhance the role of forests, trees and agroforestry in sustainable development and food security and to address climate change. CIFOR leads FTA in partnership with Bioversity International, CATIE, CIRAD, ICRAF, INBAR and TBI.

FTA's research is supported by CGIAR Fund Donors: cgiar.org/funders/

\section{Schweizerische Eidgenossenschaft Confédération suisse Confederazione Svizzera Confederaziun svizra \\ Swiss Agency for Development and Cooperation SDC}

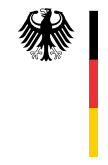

Federal Ministry for Economic Cooperation and Development

cifor.org/migration-and-forests

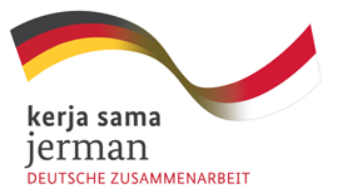

implemented by:

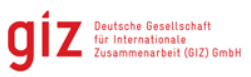

